\title{
Competitiveness of Togolese Banking Sector
}

\author{
Tunde Ahmed Afolabi \\ University of International Business and Economics, Beijing, China \\ Email: sirdanielstro12@yahoo.fr
}

How to cite this paper: Afolabi, T.A. (2018) Competitiveness of Togolese Banking Sector. Theoretical Economics Letters, 8, 2497-2519. https://doi.org/10.4236/tel.2018.811161

Received: July 12, 2018

Accepted: August 19, 2018

Published: August 22, 2018

Copyright $\odot 2018$ by author and Scientific Research Publishing Inc. This work is licensed under the Creative Commons Attribution International License (CC BY 4.0).

http://creativecommons.org/licenses/by/4.0/

\begin{abstract}
Development of a country depends on its economic growth which depends also on several factors which can be both micro and macroeconomic. The financial sector is the lung of the economy; more exactly the banking sector contributes in a non negligible part to this growth. The competitiveness, effectiveness and efficiency of banking sector make it reliable to the economy. Unfortunately, evidences have shown that most Sub-Saharan countries don't rely much on their financial sector, mainly due to challenges they face. This paper aims to analyze the competitiveness and the driving factors in Togolese banking sector with macroeconomic development using Structure-Conduct and Performance (SCP) framework and regression models. The research covers a period of sixteen years (from 2000 to 2015), with ten banks. This research proxies the asset in a panel A and profit in a panel B for the bank's competitiveness. The results are of panel regressions with fixed effects and robust standard errors. Considering the Panel A, the variables Inter-Banks loans, customers loans, Inter-Banks Debts, Customers Debts are the driving factor of the competitiveness. However, the size of the bank proxied by profit has no impact on the competitiveness. The result suggests that the reform which has started since 1990 should be completed; there should be organizational and financial restructuring.
\end{abstract}

\section{Keywords}

Competitiveness, Banking Sector, SCP Framework

\section{Introduction}

In their role as allocators of funds from savers to borrowers, banks have a central role in financial sector development. They bridge the gap between savers and entrepreneurs while also reducing some of the transactional and financial risk for both parties. By making funding available to the market, banks typically facilitate a reduction in barriers to entry for entrepreneurs. Effective banking sys- 
tems expand financing opportunities for both large and small companies, while also supporting financial sector development and the expansion of access to funding among low income retail customers and micro enterprises. Beyond funding, banks also provide essential financial services to individuals and enterprises including the collection, custodianship, safeguarding of deposits made by savers and the provision of payment services.

However, challenges either endogenous or exogenous occur in their way of playing the effective role, the Togolese banks are not exempted. The Togolese economy has been greatly weakened by the socio-political crisis of the early 90 . This has led to expand financial crisis that has affected the national income and many branches that generate income without mentioning the financial agent and other people who have seen their business decline. To patch the leaks and promote the national economy, public and private financial or not institution should be involved in banking affaires.

Convinced that the level of competitiveness matters and leads to the development through the efficiency and the effectiveness of firms or institutions in every sector of economy in a nation, this paper will pool out the competitiveness at the firm level by identifying and analyzing the development trends in Togolese banking sector with macroeconomic development using SCP framework and regression models.

\subsection{Research Objectives}

The main objective of this research is to analyze the competitiveness and the driving factors in Togolese banking sector with macroeconomic development using SCP framework and regression models.

\subsection{Hypothesis}

H1: Size influences positively the competitiveness.

H2: Loans influence positively the level of Competitiveness.

\subsection{Significance of the Research}

The aim of our paper is to help policymakers or deciders to find workable solutions to the burgeoning menace of resource abundance but still not been using properly in Togo and also in WAEMU that has other pest places in Africa and outdistances any future occurrence in Togo so as to improve the economic situation of the citizen.

\subsection{Structure of the Research}

The structure of the rest of paper is as follows: chapter two: background and literature review of the research in which we will explain the competitiveness, chapter three, research of industry structure and performance of Togo by using SCP model, chapter four research methodology with OLS by using STATA, chapter five: results and discussion and chapter 6: conclusion and policy rec- 
ommendations with our future scope.

The remainder of the paper is organized as follows. First, the background and the literature on the determinants of financial performance in both developed and emerging countries. Second is research of industry structure and performance of Togo. Follow with the methodology and the results. The final section concludes the paper with a summary of main findings as well as their implications and recommendations for further research.

\section{Background and Literature Review}

\subsection{Definition and Categories of Competitiveness}

\section{Definition}

Many writers gave definitions to the word competitiveness regards to the economics approaches, the measure instrument or index so far showing the multidimensional concept of the competitiveness. We found that it can be apprehended from three different levels: country or regional, industry, and firm level. Competitiveness originated from the Latin word, competer, which means involvement in a business rivalry for markets. Competitiveness pertains to the ability and performance of a firm, sub-sector or country to sell and supply goods and services in a given market, in relation to the ability and performance of other firms, sub-sectors or countries in the same market. It is popular to describe economics strength of an entity with according to its competitors in the global market economy in which goods, services, people, skills, and ideas move freely across geographical borders [1].

Firm level competitiveness can be seeing as the ability of firm to design, produce and or market products superior to those offered by competitors, considering the price and non-price qualities [2]. Regards to the macro view of competitiveness; The Global Competitiveness Report of the World Economic Forum defines it as "the set of institutions, policies, and factors that determine the level of productivity of a country. Competitiveness processes are those processes, which help identify the importance and current performance of core processes such as strategic management processes, human resources processes, operations management processes and technology management processes. It enhances the ability of an organization to compete more effectively.

In the scientific approach, the term "firm competitiveness" has severer definition. We can refer to the definition of Porter as the ability of a given firm to successfully compete in a given business environment. As for Lall it is the ability of a firm to do beyond benchmark companies in terms of profitability, sales, or market share. Also, Buckley, Pass, and Prescott [3] who consider the long run view of competitiveness to be synonymous with a firm's profit, performance, its ability to compensate employees and generate superior returns for shareholders. Often the competitiveness brings out the existence of good financial performance full of profitable opportunities resulting in higher production and sales. The advantage of employing financial measures is their agreed-upon definitions 
and the easiness of calculations.

In line with these definitions, this study will focus on the Structure Conduct and financial performance of a firm to measure its competitiveness of Togolese banks.

\subsection{Literature Review}

The determinants of competitiveness have been discussed in diverse ways by researchers from various disciplines such as accounting and finance, strategic management, economics. In general, findings suggested that profitability measures tend to converge towards long run average values that are specific to each firm. However, limited works have been made who's investigated the efficiency of the banking sector. Many questions about competitiveness are still not finding answers although the rich literature concerning the concept. Some important questions are still without answers like: How can frameworks and models be adapted for a particular firm in a particular stage of development with different capabilities and resources? Which strategy or plan for industries like emerging industry?

Recognizing weaknesses that can connect theory with practice, and review of select relevant frameworks and models is being done.

Capon, Farley, and Hoenig [4] with a meta-analysis reviewed 320 empirical studies and identified several strategic, environmental and organizational factors affecting financial performance. As result, they reported that the industry concentration, growth, market share, geographic dispersion of production, research and development expenditures and size measured by sales have a positive impact on the financial performance of the companies. However, the majority of the studies analyzed reported a negative relationship between financial performance and variables such as debt, diversification, imports and exports.

Giovanis and Ozdamar [5] conducted a study by analyzing the determinants of company profitability with the US Compustat database between 1976 and 2009. They authors demonstrated that firm size and debt have positive effects on profitability but only up to a certain point after which the relationship becomes negative. On the other hand the assets-to-sales, was found to have a negative impact on profitability at the beginning, but, after some point, the relationship becomes negative.

For Tailab [6] who used US Data and analyzed the variation in the financial performance of 100 top non-financial firms listed on the Fortune 500 for the period between 2009 and 2013. His findings showed that debt ratio, higher levels of inventory and growth are negatively related to profitability as measured by return on assets but the liquidity and size have a negative impact on profitability.

Gurbuz, Aybars, and Kutlu [7] with their studies on the analyzing determinants firm competitiveness or financial performance in Turkey with a sample of 164 firm-years of observations for Turkish real sector firms listed on the Istanbul Stock Exchange during the period 2005-2008. Their results showed the existence 
of a positive association between institutional ownership and financial performance measured by return on assets, with the association being stronger for firms listed on the corporate governance index.

Karabag, Lau, and Suvankulov [8] very recently have investigated the determinants of competitiveness for Turkish firms in the textile and apparel industry. They Results identified eight constructs of competitiveness, among which, three were considered as the most significant determinants of firm competitiveness in the textile and apparel industries of Turkish. These included product differentiation, efforts across foreign markets and state support. Surprisingly, the study showed very little impact of networking on firm competitiveness.

Goddard, Tavakoli, and Wilson [9] conducted a research on the factors affecting profitability for manufacturing and service sector firms in four countries in Europe: Belgium, France, Italy and the UK. The focused on the period 1993-2001 and used a dynamic panel data models, the findings showed that firm size and gearing ratio have a negative impact on profitability while the impact of market share and liquidity on profitability is positive.

Y. C. Richard Wong and M. L. Sonia Wong [10] in the research title COMPETITION IN CHINA'S DOMESTIC BANKING INDUSTRY, examined the level and conditions of competition that can existed between the domestic banking since 1994. They found the evidence of an institutional impact on the effective and efficient competition in the banking sector. And also the existence of the weakness of degree of Competitiveness between banks, and its role in improving banking efficiency has been limited. They advised that fundamental institutional and practicable change must be done before China will enjoy the full benefits of increasing competition once it has attained membership in the WTO. In this paper they made for the competitiveness a quantitative evaluation by through SCP, according to the structure Herfindahl indexes for credits deposits and asset show that the market structure of China's domestic banking industry is oligopolistic. And it dominated by four state commercial banks when we consider the liability. But the reciprocal of the Herfindahl index for profits point out that there is an important decrease in the level of concentration in the Banking sector. The concentration indexes point out that the deposits-and-loans market is dominated by state-owned commercial banks. Those banks, however, fail to capture a comparable share of the profits.

The research done by Oberholzer \& Van der Westhuizen [11] was tight in scope in that it researched the efficiencies of ten branches of one local bank. The other work done by Bedari [12] in this field was focused on banks in Botswana and Namibia and the three South African banks covered in the study were only used for comparison purposes. Ikhide [13] also in 2000, conducted research on banks in Namibia, from 1996 to 1998 and made a comparison these results to those for other countries in the Sub-Saharan countries, also South Africa.

It is impossible to talk about competiveness underestimating it relation with concentration and the stability. The empirical literature mention on the direct 
relationship between competitive conduct of financial institutions and its bearing for concentration is small. This is surprising, given the issues of competitiveness and concentration in the banking industry are heavily debated by some policymakers.

Oppose to these results, Claessens and Laeven [14] used in 2004 a sample of 50 countries with four different models to compute the H-Statistic and report that their analysis provides empirical support for a positive association of concentration and competition. They discovery is robust to the incorporation of regulatory variables that capture contestability of the banking systems in the countries under consideration.

Claessens and Laeven [14] concluded that the degree of concentration is not the best measure because it is a poor indicator for the competitive environment. Beside, Carbo et al. [15] in 2006 compared different measures of market power in European banking and reiterate that there is little relationship between measures of market structure, such as the Herfindahl-Hirschman Index and the H-Statistic, and Staikouras and Koutsomanoli-Fillipaki [16] report that EU countries have experienced a substantial increase in competition during the period 1998-2002, while they simultaneously find evidence for higher levels of concentration among European banking systems.

Finally, according to Ceterelli [17], who used Italian bank data, contradicted the SPC which is regarding the relationship between concentration and competition. He indicated that through the restoration of market competition, merger activities within banks can break up collusive arrangements. He also concluded that, high seriously misleading inferences regarding the exercise of market power is a result of increase in concentration measures.

\subsection{Competition and Stability}

According to Matutes and Vives [18], argued that regardless of the structure of the market, instabilities will always be there because, based on the Diamond and Dybvig [19] model depositors' propensity to run is determined exogenously by their expectations. In contrast, Smith [20] puts forward a theoretical exposition of how increasing competition for bank deposits gives rise to vulnerabilities in the system.

Besanko and Thakor [21] illustrate that when competition among banks becomes solid, banks can decide to go as far as taking risky portfolio strategies. Taking into account the design of deposit insurance schemes, Cordella and Yeyati [22] shows that risk based deposit insurance restrains risk taking behavior of financial institutions even in the presence of increased competition whilst fierce competition in an environment with flat-fee deposit insurance translates into higher risk in the system. With exception of the study by Matutes and Vives [18] all the aforementioned theoretical studies imply a positive association between competition and fragility, and this is therefore referred to as "competition-fragility" literature. According to, Koskela and Stenbacka (2000) who used 
the mean-shifting investment technologies model demonstrated that there is no need to be a trade-off between competition and stability.

But for our research after using the SCP to describe the environment of WEAMU and Togolese Banking Sector earlier in Chapter One, we will use OLS model by proxy the Competitiveness as the Asset. In regards of the literatures we went through, this paper will be the first to cover the Togolese banking sector in matter of its competitiveness with addiction of SCP framework. It gives a general overview of the financial sector and it efficiency.

\subsection{Competitiveness Framework}

Many papers and publications at micro-level competitiveness have yet made a real impact on competitiveness practices among firms. Interactions with industry professionals during research clearly hint that very few professionals have clarity about the way competitiveness interventions can be done, performed, and incorporated with existing method or new ones for rapid increment of competitiveness.

Although Competitiveness can be used as a dependent or independent variable, function of the perspectives from which one takes, our study is taking it as dependent variable. Berkely et al. [23] advised a framework that has three folds: firstly the competitiveness performance, secondary it's potential, and last the management processes. We can find an analogous research in the World Competitive Yearbook (WCY, 2002).

So when we talk about Competitiveness we mention "association of assets and processes, where assets are from natural resources or created such as infrastructure and processes transform assets to achieve economic gains from sales to customers" (DC, 2001). Outputs can be realized through competitive potentials by the competitiveness process [23], similar to the Asset-Process-Performance (APP) framework [24].

Some writers have seen competitiveness with the competency approach. They underlined the role of factors internal to the firms such as firm strategy, structures, competencies, capabilities to innovate, and other tangible and intangible resources for their competitive success [25] [26] [27]. This view is particularly among the resource-based approach towards competitiveness [27] [28] [29] [30] [31].

Banks to realize their profit receive deposits and they make loans and get their profit from the difference in the interest rates paid and charged to depositors and borrowers respectively. The routine makes by banks by taking funds from a depositor and then lending them out to a borrower makes them to be a financial intermediation. Through this service, certain assets are changed into different assets or liabilities. As such, financial intermediaries channel funds from people who have extra money or surplus savings (savers) to those who do not have enough money to carry out a desired activity (borrowers). Doing this Banks sometimes face challenges, the ability to solve these issues depends on why they 
manage or are organized. And the most important challenge the banks face are the financing and information asymmetries.

Information asymmetries have been studied by several authors through different theories including the theory of moral hazard and adverse selection. These problems caused by the existence of asymmetric information for understanding the behavior of banks in the credit granting (selection of borrowers, supervision of borrowers, collateral, credit rationing ...). The determinants of asymmetric information between lenders (banks) and borrowers (firms), and based on the approach "principal (lender), agent (the borrower)". Akerlof [32], decentralized transactions based only on price, in another words, the interest rate or the expected return, is not generally possible to achieve balance for bank credit. On the credit market, the traded good is not a homogeneous good; delivery and payment can be very distant in time. In fact, the credit is issued today against a promise to pay in the future. This creates a risk of non-repayment which the borrower and the lender have different opinions.

As regards to these points of view, how Togolese baking sector is organized and how competitive it is. In the following chapters we will answer these questions.

\section{Research of Industry Structure and Performance of Togo}

In the Chapter, it will be question of the history of the banking sector and the application of Structure-Conduct and Performance (SCP).

\subsection{Historical of Banking in Togo}

Like in most of the African countries, the banking system in Togo was made by the colonizers. The finance was ruled by a Bank created by Napoleon for all the French colonization countries. In 1958 the Togolese official government has taken control of the banking sector by replacing the French entities, creating, innovating and entering the regional banks organization named BCEAO" Central Bank of the west African states". The "Issue Institute of French West Africa and Togo" became BCEAO the 4 April 1959. Shortly after Togo's independence the first Bank UTB was created in June 1964. With their asset, the financial sector according to World Bank 2012, has participate $62 \%$ of the total amount of GDP. Togolese financial sector is composed of commercial banks, insurance companies, financial establishments, international financial institutions and micro-finance, regulation institutions, and but dominated by the commercials banks.

Currently, the Togolese financial sector is comprised of 16 banks: Banque Centrale des Etats de l'Afrique de l'Ouest (BCEAO), Banque Atlantique Togo (Banque Atlantique); Banque Internationale pour l'Afrique au Togo (BIA-TOGO); Banque Populaire pour l'Epargne et le Crédit (BPEC); Bank Of Africa Togo; Banque Sahélo-Saharienne pour l'Investissement et le Commerce-Togo (BSIC-TOGO); Coris Bank International-Togo (CBI-Togo); Banque Togolaise pour le Com- 
merce et l'Industrie (BTCI); Succursale de Diamond Bank au Togo; Succursale de la Société Générale-Bénin au Togo (Société Générale-Togo); Ecobank-Togo; ORABANK TOGO; Société Inter Africaine de Banque (SIAB); Union Togolaise de Banques (UTB); Caisse Régionale de Refinancement Hypothécaire de l'UEMOA (CRRH-UEMOA) and Fonds de Garantie des Investissements Privés en Afrique de l'Ouest (GARI).

But our focus will be only on the commercial banks which are facing some challenges while some have merged changing then the structure of the sector. The two public banks, accounting for about 20 percent of Togo's banking sector assets, have breached the 8-percent solvency ratio requirement, as has one other bank. Three banks have a negative solvency ratio. With an aggregate solvency ratio of only 3.8 percent, the banking system as a whole is undercapitalized as well. This compares unfavorably with the WAEMU area, where the aggregate solvency ratio stands at about 11 percent. Excluding the state-owned banks brings Togo back in line with the WAEMU average. This illustrates that the core of the problem lies with these two public banks. The Togolese banking sector is too limited in number of sectors. Credit to the retail sector makes up 35 percent of total loans, while credit related to public works amounts to 22 percent, which is particularly high relative to a WAEMU average of around 8 percent. In addition, there is concentration risk with respect to borrowers: credit to five largest borrowers' stands at 140 percent of capital in Togo, compared to 94 percent in the WAEMU. Close to $20 \%$ of the total loans is classified as non-performing. In WAEMU, the Togolese banking sector performance is the worst.

The domestic banks have financed the fiscal deficits of Togo. The non-state banks hold the largest claims on the government and are thereby also most-exposed to sovereign risk. As a result, Togolese government securities now make up about 15 percent of commercial banks' balance sheets. This has increased the banking sector's exposure to sovereign risk.

Indeed the share of the State in the banking sector is big. At the heart of the banking system is the Central bank named BCEAO. It's the central bank of the WEAMU's countries. BCEAO was created the 4th April 1959. BCEAO is in charge of the WEAMU's countries and plays the role of regulator by implementing monetary policies, determining interest rates, controlling money supply, lender of last resort, regulating and supervising the banking industry, managing foreign reserves and gold reserves, and controlling the money supply.

\subsection{Industry Structure and Performance of Togo}

For many decades, economists have conducted structure-conduct -performance (SCP) studies that concentrate on what are the major factor that determines market power which concerns the relationship between market performance and market structure. Market Performance is the success of the market in producing benefits for consumers. Market Structure consists on those factors that determine the competitiveness of a market (for example, a market is performing well 
if prices are near the marginal cost of production). Market structure affects market performance through the conduct or behavior of firms. Traditionally, SCP researchers presume that market power or performance can be measured relatively easily, and concentrate on the relationship between performance and structure. The traditional approach to empirical industrial organization research was a revolutionary change when it was introduced by Edward S. Mason (1939, 1949) and his colleagues at Harvard. Most of the earlier work dealt with case studies of single industries (Wallace 1937 for example). The predictions based on Market Structure are summarized in Table 1.

This table basically provides in a scientific way the expectation of the maximized profit. In a perfect competitive market the profit maximization is zero showing that all the firms are price takers and for the Monopolistic competition, Monopoly and Oligopoly it is positive due to the imperfection of the market. For the short run profit, a negative profit will lead to the exit of the firm otherwise remain. As for the long run profit it can't never be less than zero.

\subsection{Industrial Structure of Togo}

Our studies of the industrial structure will only focus on the commercial banks in Togo. They are in total of: Banque Atlantique Togo (Banque Atlantique); Banque Internationale pour l'Afrique au Togo (BIA-TOGO); Banque Populaire pour l'Epargne et le Crédit (BPEC); Bank Of Africa Togo; Banque Sahélo-Saharienne pour l'Investissement et le Commerce-Togo (BSIC-TOGO); Coris Bank International-Togo (CBI-Togo); Banque Togolaise pour le Commerce et l'Industrie (BTCI); Succursale de Diamond Bank au Togo; Succursale de la Société Générale-Bénin au Togo (Société Générale-Togo); Ecobank-Togo; ORABANK TOGO; Société Inter Africaine de Banque (SIAB) and Union Togolaise de Banques (UTB) (Figure 1).

According to the chart that represents the data collected from the WAEMU, the financial bank comes first with $26 \%$ of the total share, followed by Ecobank $23 \%$ and UTB $13 \%$, while the former Orabank is having only $1 \%$. This describes the environment before the merging of BTD and Financial Bank on $14^{\text {th }}$ February 2014. This structure has changed years later because BRS another commercial bank has associated with the merge on $16^{\text {th }}$ November 2015 by forming a new Orabank.

Table 1. Market structure.

\begin{tabular}{cccc}
\hline & p-MC & $\pi_{S R}$ & $\pi_{L R}$ \\
\hline Competition & 0 & + or - & 0 \\
Monopolistic competition & + & + or - & 0 \\
Monopoly & + & + or - & + or 0 \\
Oligopoly & + & + or - & + or 0
\end{tabular}

Source: Modern Industrial Organization (page 237). $\mathrm{P}=$ price, $\mathrm{MC}=$ marginalcost (shortrun), $\pi_{S R}=$ short run profit and $\pi_{L R}=$ long run profits. 


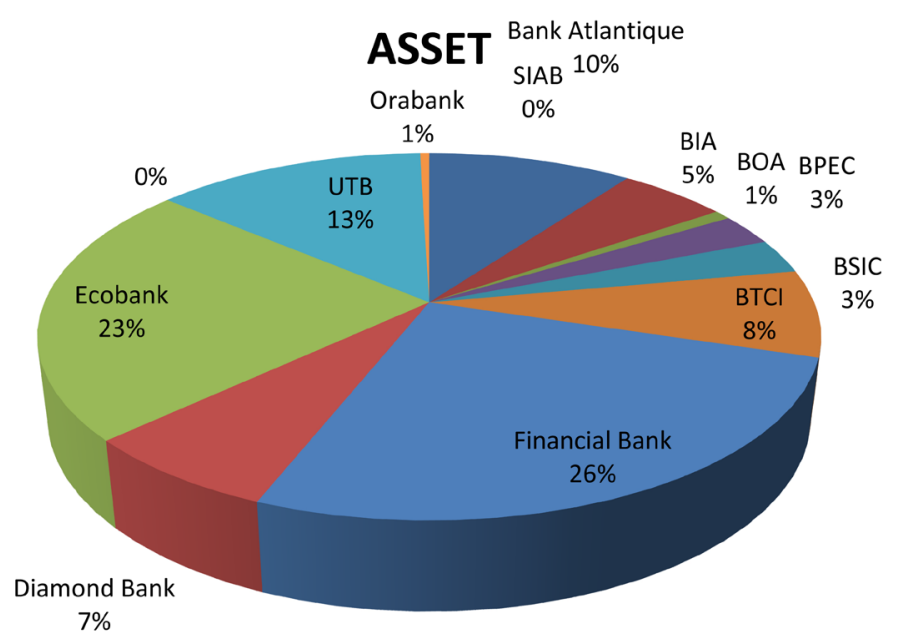

Figure 1. The share in Asset of Bank in 2013. Source: WAEMU 2013.

Figure 2 shows us how the structure has changed.

The financial Bank, BTD and BSR have become Orabank is occupying the first place with $25 \%$ a marginal decrease from $26 \%$ to $25 \%$ while Ecobank from $23 \%$ to $18 \%$. We have a slightly increment of Diamond bank from $7 \%$ to $11 \%$, BOA from $1 \%$ to $5 \%$.

Now let us use the profit of the banks with the concentration ration to see how the top 5 banks are structured. In most of SCP studies, industry concentration is the structural variable that is emphasized. Industry concentration is typically measured as function of the market shares of some or the entire firm in the market. The value of " $n$ " is often five, but may be four, three or any small number. If the top " $n$ " firms gain the market share, the industry is said to have become a highly concentrated. More $C R_{n}$ value more the concentration.

$$
C R_{n}=\left(\sum_{i=1}^{n} X i / \sum_{i=1}^{n} X i\right) \times 100 \%
$$

with our calculation we get the $\mathrm{C} 5$ concentration ratio (Figure 3), the result give us a clear picture of an oligopoly industry because only the share of Ecobank and UTB $(54.79+18.301=73.091 \%)$ is more than the $60 \%$. Further we can say that the Togolese Banking Sector is in Dominant Monopoly just because Ecobank with its profit conquers the market for over $50 \%$.

We conclude by there that even though Orabank is leading with the highest Asset in the banking sector is not making profit such as Ecobank does. A bank can have more Assets but it doesn't mean that it realizes the big profit.

\subsection{Market Conduct of Togo}

Banks in Togo had relatively high interest margins reflecting low interest rates on deposits and comfortable lending rates. Most savings rates were near the regulated 3.5 percent nominal annual rate. Loan rates fluctuated in a range of 4 to 5 percentage points above the base rate (taux de base bancaire). Generally, the maximum applied lending rate was 14 to 15 percent. But lending rates could be 


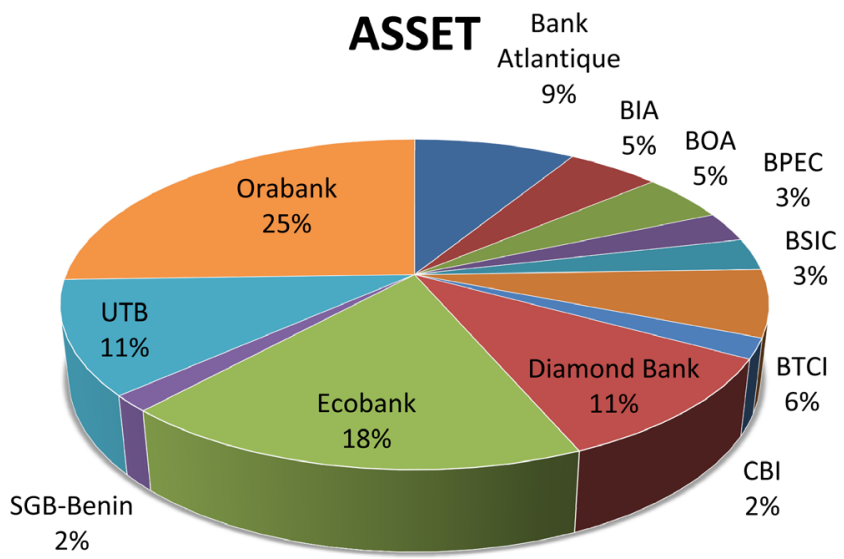

Figure 2. The share in Asset of Bank in 2015. Source: WEAMU 2015.

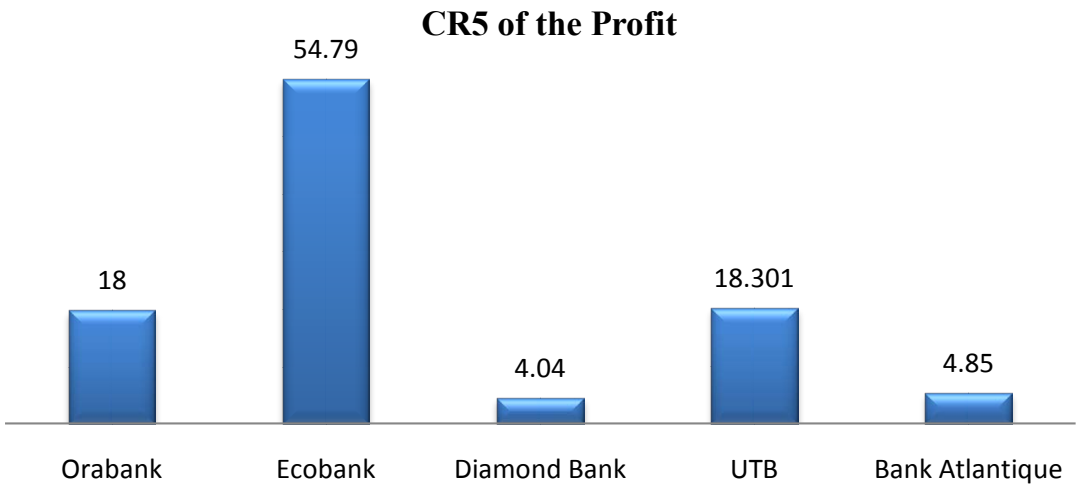

Figure 3. Concentration Ratio of the profit. Source: WEAMU.

as low as 9 percent. Interest margins ranged from 7.9 percent at BIA to 18.7 percent at BTD. Banks with higher margins such as BTD and Ecobank were consistently profitable year after year from 2000 to 2004. From 2009, the performance of banks was not likely to be the same, competition within the sector brought the situation almost close to real market equilibrium. In 2009, banks loan rate fluctuated between 9 and $10 \%$. This low rate is due the overall financial market that is the fact of the microfinance loan supply, rate for non-term deposit is up to $4.6 \%$ the same period.

In a contestable market, which is characterized by the threat of entry, a firm is unable to raise its prices above marginal cost. Thus a high concentrated market can be competitive if firms can enter and exit freely.

\subsection{Major Aggregates}

\subsubsection{Loans and Deposits}

There is a strange trend in the Togolese banking industry. The amount of short term loans is ten times superior to the long term loan. The commercial banks are willing to give more short loans and medium loans than long term loans. This trend is justified. The Commercial Banks usually face insolvency problems and because of that, they prefer to grant short term loans or medium term loans ra- 
ther than long term loans. The economic agents are not willing to make long term loan because in the world Togo has one of the lowest ratio in weakness rate of loans and deposit. One thing which is also important in this industry is how Commercial Banks run.

For the Togolese Commercial Banks we will focus on how they transform deposits to loan because that is one of their main activities. In 1990s the gap was small between the deposits and loans. In fact the amount of loan was superior to the amount of deposit although the trend is low. The simple explanation is that, at the beginning the banking sector promoted Banking activities and to attract as many costumers as possible. Also the Commercial Banks had some support from the government. From 2000 the situation started to change because of the past crisis, the new regulations and also the fear of Commercial Banks. Nowadays the gap is really big between the loans and the deposits, and the amount of deposit is higher than loans one.

\subsubsection{Overdue Credit}

Another characteristic of commercial banks in Togo is the high level of insolvency. The overdue credit has never been stable (Figure 4). This fact explains perfectly the fear of Commercial banks to grant long term loans. The insolvency is a serious problem which affects considerably the performance of the Commercial Banks. Creditor's insolvency makes banks reluctant, and also destroys slowly the economy.

In Togo commercial Banks have been strict regarding this issue since the 2008 financial crisis. Before granting the loan they usually make sure that you fulfill all the requirements and even after granting the loan they have a follow up policy to help the borrower. From the graph 6 we can observe that overdue credit was at his peak in 2007. After the implementation of new policies in 2008; the amount of overdue credit has seriously dropped to 9765 billion of XAF at the end of 2008.

\subsection{Market Performance of Togo}

Regards to the performance of the Togolese sector, the next chapter will deeply

Overdues Credit

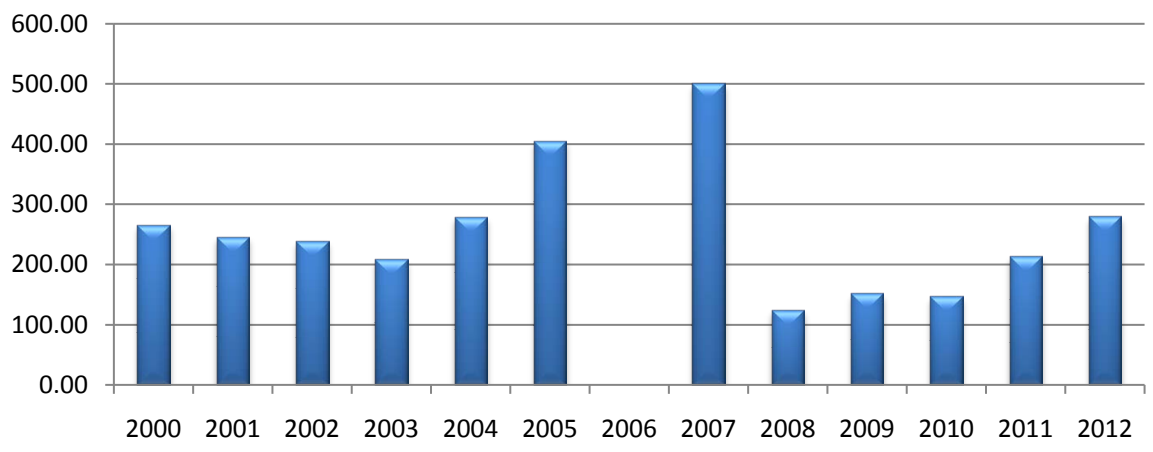

Figure 4. Evolution of the overdue credit in Togo. Source: BCEAO Statistical year book. 
and closely discuss about it using a regression model. However a research conduct by Kodjo Daniel SESSI [33] on The efficiency of a banking sector: Case of Togolese Commercial Bank using the Malmquist total factor productivity based on DEA model (which is the most popular one) from 2002 to 2010 with Eight Banks assumed each firm was efficient and derived a translog specification Malquist index to a distance function. He found that, the worst performer of the Togolese Banking industry is: Financial Bank (ex-SNI \& FA), followed by UTB and BTCI and the Best performers are BIA, BTD, ECOBANK and SIAB. They had even reached the perfect efficiency as financial intermediaries. Most of the best performers are private Banks or jointly owned banks where the private has the majority of the share.

Considering the Togolese banking industry as one He found that from 2002 to 2004 this sector was inefficient and from 2005 to 2008 it was efficient.

\section{Research Methodology}

This section is devoted to the presentation of the analytical method, the size of the series and the sources of data used in this study.

\subsection{Analysis Method}

It is in this part to expose the theoretical model of reference with its limitations and its extensions with its contributions.

Our objective is to identify and analyze the development trends and selected factors of competitiveness and growth of banking sector in Togo in relation with macroeconomic development using regression models. The following main methods are used to achieve the aim: the method of empirical sector and trend analysis, regression and correlation analysis, economic modeling and synthesis. In processing of study, the information from specialized economic and scientific literature, electronic information sources, statistical data of Statistical Office of Togo and WAEMU, available analytic data from the WEAMU Bank balances, Analyses of the Togolese banking sector, yearly data and World Bank, are used.

The analysis of current status of competitiveness of banking sector 10 banks in relation to selected indicators of banking Asset, Risk, Interbank Debt, Customer Debt, Interbank Credit, Customer Credit and the Growth of economy in Togo within the WEAMU, the analysis of financial stability of banking sector of Togo from the aspect of profitability, the empirical sector analysis, STATA will be used.

\subsection{Data Processing}

To analyze the competitiveness and the driving factors in Togolese banking sector, we collect data from the West African Central Banks (BCEAO) database which provides information concerning all the Banks that are operating in West Africa. The big part of the data was collected from "Bilan et Compte Resultat des Banques et Etablissement financiers de l'UEMOA" which contains exhaustive 
series on Bank sheets and also on Income statement. The "Rapport Annuel de la Commission Bancaire" had also been a great source of information. We need to mention that the data from BCEAO is the most reliable one we can get, and their database is usually updated. Our panel balanced data refers to multi-dimensional data frequently of one year involving measurements. It contains observations of multiple phenomena obtained over thirteen periods for the banks and the hall industry of banks. The reason why we use this form of data is because it usually gives the researcher a large number of data points, increasing the degrees of freedom and reducing the collinearity among explanatory variables. More importantly, longitudinal data allow a researcher to analyze a number of important economic questions that cannot be addressed using cross-sectional or time-series datasets.

\subsection{Variables}

For the purpose of this study, the competitiveness will be proxy by a firm's financial performance. It is measured alternatively with two financial variables the total deposit (Assets) and the Profits. They are helpful tools for the investors and economic decision makers to invest. Bank assets are the physical and financial "property" of a bank, what a bank owns. While a bank commonly owns physical property (buildings, land, furniture, equipment), the bulk of a bank's assets are financial legal claims on the property or the wealth of others and positively related to the profit.

Based on the variables that have been studied in the previous literature, a relationship between the competitiveness and several explanatory variables is suggested in the following form (Table 2).

Competitiveness $=\mathrm{f}$ (Inter-Banks loans, Customers loans, Inter-Banks Debts, Customers Debts, Risk, Savings Rate, Share of Banks in the GDP, GDP per Capita).

The above relation will be estimated with regression analysis.

\subsection{Estimation}

Using the variables presented above (Table 2), two alternative regression equations will be estimated, each regressing one of the two dependent variables on the same set of explanatory variables. Due to the structure of our dataset, panel data estimation will be employed. The model to be estimated is as follows:

$$
\begin{gathered}
Y_{i t}=\beta_{0}+\beta_{1} X_{i t}+\varepsilon_{i t}, \\
\varepsilon_{i t}=\alpha_{i}+n_{i t},
\end{gathered}
$$

where $Y_{i t}$ is one of the competitiveness measures (Asset, profit) for firm $i$ in year $t, X_{i t}$ is theset of exogenous observable characteristics of the firm $i, \beta_{0}$ and $\beta_{1}$ are parameters to be estimated, $\varepsilon_{i t}$ is the error term, $\alpha_{i}$ is the individual effect component of the error term, and $n_{i t}$, is the time-variant component of the error term. 
Table 2. Definition of variables.

\begin{tabular}{|c|c|c|c|}
\hline Variable & Definition & Denote as & Expected sign \\
\hline Profit & & Prof & + \\
\hline Asset & $\begin{array}{l}\text { The physical and financial "property" of a } \\
\text { bank, what a bank owns }\end{array}$ & Ass & - \\
\hline Interbank loan & $\begin{array}{l}\text { Sum of money that banks borrow or } \\
\text { lends among each others }\end{array}$ & InLn & + \\
\hline Customer loan & $\begin{array}{l}\text { The amount of money the customers } \\
\text { borrow from the banks }\end{array}$ & CuLn & + \\
\hline Interbank Debt: & $\begin{array}{l}\text { Amount that one bank owes the other } \\
\text { banks }\end{array}$ & IDbt & - \\
\hline Customer Debt: & $\begin{array}{l}\text { The amount of money the Customers } \\
\text { have in the Bank }\end{array}$ & Cubt & - \\
\hline Risk & $\begin{array}{l}\text { This determines the risk aptitude of a } \\
\text { particular bank in making investments }\end{array}$ & Risk & + \\
\hline Real GDP Growth & & rgdp_gr & + \\
\hline Saving Rate & & SR & + \\
\hline Share of Banks in the GDP & & Sbgdp & + \\
\hline GDP per Capita & & Grat & + \\
\hline
\end{tabular}

Source: From us.

Due to the heterogeneity which can occur because of omitted variables that affect the financial performance, a different intercept should be modeled for each firm. We have two ways to accomplish this: the fixed effects model and the random effects model.

The Hausman specification test is the classical test of whether the fixed or random effects model should be used. The research question is whether there is a significant correlation between the unobserved firm-specific random effects and the regressors. If there is no such correlation, then the random effects model may be more powerful and parsimonious. If there is such a correlation, the random effects model would be inconsistently estimated and the fixed effects model would be the model of choice. The Hausman test is a kind of Wald chi-square test with $\mathrm{k}$ degrees of freedom (where $\mathrm{k}$ equals the number of regressors) on the difference matrix between the variance-covariance of the fixed effects with that of the random effects model.

Moreover, Table 3 reports pairwise correlation coefficients between the independent variables. As can be seen, all coefficients remain below the threshold value of 0.7 ; therefore, multicollinearity is not a concern.

\subsection{Descriptive Statistics}

We will present the regression analysis and discuss the variables that impact the competitiveness of the banking sector. As first we present the table of descriptive statistics of the variables employed in this research. According to Table 4, the average Asset is 103,717.5 XOF, while for the Profit is 16,842.21 XOF. As for the independent variables, it is seen that the average loan interbank is $20,636.56$ 
Table 3. Correlation matrix.

(a)

\begin{tabular}{ccccccccc}
\hline & inln & culn & idbt & cdbt & risk & rgdp_gr & sr & sbgdp \\
\hline inln & 1.0000 & & & & & & & \\
culn & 0.3012 & 1.0000 & & & & & & \\
idbt & 0.3597 & 0.8092 & 1.0000 & & & & & \\
cdbt & 0.5457 & 0.9015 & 0.6571 & 1.0000 & & & & \\
risk & -0.0594 & 0.0757 & -0.0061 & 0.0126 & 1.0000 & & & \\
rgdp_gr & 0.1151 & 0.2962 & 0.2521 & 0.2859 & 0.2405 & 1.0000 & & \\
sr & 0.0560 & 0.1266 & 0.0941 & 0.1029 & 0.1700 & 0.3572 & 1.0000 & \\
sbgdp & 0.1703 & 0.3987 & 0.3632 & 0.3421 & 0.2415 & 0.5601 & 0.3820 & 1.0000 \\
\hline
\end{tabular}

(b)

\begin{tabular}{ccccccccr}
\hline & Inln & Culn & Idbt & Cdbt & Risk1 & Rgdp_gr & Sr & Sbgdp \\
\hline Inln & 1.0000 & & & & & & & \\
Culn & 0.4021 & 1.0000 & & & & & & \\
Idbt & 0.4704 & 0.8290 & 1.0000 & & & & & \\
Cdbt & 0.5964 & 0.9239 & 0.7119 & 1.0000 & & & & \\
Risk1 & -0.1144 & 0.2635 & 0.3528 & 0.1147 & 1.0000 & & & \\
Rgdp_gr & 0.2486 & 0.3144 & 0.2806 & 0.3112 & -0.0505 & 1.0000 & & \\
Sr & 0.2414 & 0.0942 & 0.1023 & 0.1207 & -0.1668 & 0.3982 & 1.0000 & \\
Sbgdp & 0.2876 & 0.4710 & 0.4384 & 0.4118 & -0.0616 & 0.5586 & 0.4577 & 1.0000 \\
\hline
\end{tabular}

Source: From us.

Table 4. Descriptive statistics.

\begin{tabular}{cccccc}
\hline Variable & $\mathrm{N}$ & Mean & Std. Dev. & Min & Max \\
\hline Ast & 115 & 103717.5 & 91014.42 & 4527 & 503475 \\
prof & 103 & 16842.21 & 25897.67 & 0 & 175978 \\
Inln & 115 & 20636.56 & 20678.36 & 1796 & 83665 \\
Culn & 115 & 53167.17 & 52744.71 & 441 & 278556 \\
Idbt & 115 & 18304.56 & 27001.66 & 0 & 160530 \\
Cdbt & 115 & 72212.67 & 60891.97 & 764 & 284867 \\
Risk & 106 & 696.9151 & 1970.121 & 0 & 8067 \\
risk1=1/risk & 65 & 0.0216286 & 0.0370775 & 0.000124 & 0.12 \\
rgdp_gr & 160 & 3.1875 & 3.550512 & -5 & 7 \\
Sr & 160 & 5.375 & 3.399501 & 0 & 13 \\
Sbgdp & 160 & 31.9375 & 20.55662 & 4 & 69 \\
\hline
\end{tabular}

Source: From us.

XOF while the average of debt interbank is $18,304.56$ XOF. Considering the customer, their average loan to the bank is $72,212.67 \mathrm{XOF}$ as contrary the average 
owe the bank is $53,167.17$ XOF. The banking sector contributes by mean value of almost 4 to the share of the GDP, however has an average growth value of 3.18 and a saving rate mean value of 5.37. In the sample the risk perceived by the banks toward the regular customers is $2.16 \%$ (what is relatively low).

\subsection{Estimation Results}

The results of the estimation are presented in Table 5. According to the results of the first model, which are displayed in Panel A, the variables Inter-Banks loans, Customers loans, Inter-Banks Debts, Customers Debts are statistically significant while, Risk, Savings Rate are not significant but what we noticed

Table 5. Estimation results. (a) Fixed Effect; (b) Random Effect; (c) Hausman Test; (d) Fixed Effect; (e) Random Effect; (f) Hausman Test.

(a)

\begin{tabular}{ccccccc}
\hline \multicolumn{7}{c}{ Panel A: Dependant Variable: Asset } \\
\hline Variable & Coef. & Robust Std. Err & $\mathrm{T}$ & $\mathrm{p}>\mathrm{t}$ & [95\%Conf. Interval] \\
\hline inln & 0.6134129 & 0.1946732 & 3.15 & 0.003 & 0.2222025 & 1.004623 \\
culn & 1.14259 & 0.1271146 & 8.99 & 0.000 & 0.8871434 & 1.398036 \\
idbt & 0.3783463 & 0.1268511 & 2.98 & 0.004 & 0.1234293 & 0.6332632 \\
cdbt & 0.365955 & 0.086704 & 4.22 & 0.000 & 0.1917168 & 0.5401932 \\
risk1 & 84138.64 & 49399.23 & 1.70 & 0.095 & -15132.84 & 183410.1 \\
rgdp_gr & -734.5819 & 581.0447 & -1.26 & 0.212 & -1902.235 & 433.0711 \\
sr & 940.5316 & 530.9491 & 1.77 & 0.083 & -126.4507 & 2007.514 \\
sbgdp & -289.7793 & 117.2131 & -2.47 & 0.017 & -525.3279 & -54.23068 \\
_cons & 2154.803 & 3787.281 & 0.57 & 0.572 & -5456.022 & 9765.628 \\
\hline
\end{tabular}

Fixed-effects (within) regression, Number of obs $=65$, Group variable: id, Number of groups $=8$, R-sq: within $=0.9912$, Obs per group: $\min =3$, between $=0.9545$, avg $=8.1$, overall $=0.9866, \max =16, F(8,49)$ $=688.46, \operatorname{corr}\left(\mathrm{u} \_\mathrm{i}, \mathrm{Xb}\right)=-0.1759, \operatorname{Prob}>\mathrm{F}=0.0000$.

(b)

\begin{tabular}{ccccccc}
\hline \multicolumn{5}{c}{ Panel A: Dependant Variable: Asset } \\
\hline Variable & Coef. & Robust Std. Err & $\mathrm{z}$ & $\mathrm{p}>\mathrm{z}$ & [95\%Conf. Interval] \\
\hline inln & 0.773034 & 0.1401277 & 5.52 & 0.003 & 0.4983888 & 1.047679 \\
culn & 1.049104 & 0.1205646 & 8.70 & 0.000 & 0.8128016 & 1.285406 \\
idbt & 0.4283665 & 0.108414 & 3.95 & 0.000 & 0.2158791 & 0.640854 \\
cdbt & 0.3569711 & 0.0917278 & 3.89 & 0.000 & 0.1771879 & 0.5367543 \\
risk1 & 62400.02 & 48232.59 & 1.29 & 0.196 & -32134.11 & 156934.2 \\
rgdp_gr & -252.4336 & 612.8543 & -0.41 & 0.680 & -1453.606 & 948.7389 \\
sr & 732.4181 & 600.2713 & 1.22 & 0.222 & -444.0921 & 1908.928 \\
sbgdp & -124.4374 & 103.1939 & -1.21 & 0.228 & -326.6937 & 77.81888 \\
cons & -1761.242 & 4200.777 & -0.42 & 0.675 & -9994.613 & 6472.129 \\
\hline
\end{tabular}

Random-effects GLS regression, Number of obs $=65$, Group variable: id, Number of groups $=8$, R-sq: within $=0.9900$, Obs per group: $\min =3$, between $=0.9738$, avg $=8.1$, overall $=0.9891$, $\max =16$, Random effects u_i $\sim$ Gaussian, Wald chi2 $(8)=5094.28$, corr $\left(u \_i, X\right)=0$ (assumed), Prob $>$ chi2 $=0.0000$. 
(c)

\begin{tabular}{ccccc}
\hline & $\mathrm{Fe}(\mathrm{b})$ & $\operatorname{Re}(\mathrm{B})$ & Difference $(\mathrm{b}-\mathrm{B})$ & S.E sqrt (diag (V_b - V_B $)$ ) \\
\hline inln & 0.6134129 & 0.773034 & -0.1596211 & 0.1351365 \\
culn & 1.14259 & 1.049104 & 0.0934858 & 0.0402776 \\
idbt & 0.3783463 & 0.4283665 & -0.0500203 & 0.0658606 \\
cdbt & 0.365955 & 0.3569711 & 0.0089839 & \\
risk1 & 84138.64 & 62400.02 & 21738.61 & 10672.48 \\
rgdp_gr & -734.5819 & -252.4336 & -482.1484 & \\
sr & 940.5316 & 732.4181 & 208.1135 & \\
sbgdp & -289.7793 & -124.4374 & -165.3419 & 55.58727 \\
\hline
\end{tabular}

$\mathrm{b}=$ consistent under Ho and Ha; obtained from xtreg, $\mathrm{B}=$ inconsistent under Ha, efficient under Ho; obtained from xtreg, Test: Ho: difference in coefficients not systematic, chi2 $(4)=(\mathrm{b}-\mathrm{B})^{\prime}\left[\left(\mathrm{V} \_\mathrm{b}-\right.\right.$ V_B $\left.)^{\wedge}(-1)\right](b-B)=5.71$, Prob $>$ chi2 0.2217 , (V_b - V_B is not positive definite).

(d)

\begin{tabular}{ccccccc}
\hline \multicolumn{7}{c}{ Panel B: Dependant Variable: Profit } \\
\hline Variable & Coef. & Robust Std. Err & $\mathrm{T}$ & $\mathrm{P}>\mathrm{t}$ & [95\%Conf. Interval] \\
\hline Inln & -0.9590563 & 0.2723842 & -3.52 & 0.001 & -1.508011 & -.410102 \\
Culn & -0.1615069 & 0.1779 & -0.91 & 0.369 & -.5200409 & 0.197027 \\
idbt & -0.3216496 & 0.1821708 & -1.77 & 0.084 & -.6887908 & 0.0454915 \\
cdbt & 0.6761806 & 0.1214692 & 5.57 & 0.000 & 0.4313756 & 0.9209856 \\
risk1 & -15439.52 & 70398.94 & -0.22 & 0.827 & -157319.3 & 126440.2 \\
rgdp_gr & -462.7228 & 853.7523 & -0.54 & 0.591 & -2183.348 & 1257.902 \\
sr & 1463.072 & 801.7946 & 1.82 & 0.075 & -152.8389 & 3078.983 \\
sbgdp & -135.3294 & 165.3162 & -0.82 & 0.417 & -468.5023 & 197.8435 \\
_cons & -4668.048 & 6411.573 & -0.73 & 0.470 & -17589.72 & 8253.627 \\
\hline
\end{tabular}

Fixed-effects (within) regression, Number of obs $=60$, Group variable: id, Number of groups $=8$, R-sq: within $=0.6934$, Obs per group: $\min =3$, between $=0.3422$, avg $=7.5$, overall $=0.5236, \max =13, \mathrm{~F}(8,44)$ $=12.44$, corr $\left(\mathrm{u} \_\mathrm{i}, \mathrm{Xb}\right)=-0.5941$, Prob $>\mathrm{F}=0.0000$.

(e)

\begin{tabular}{ccccccc}
\hline \multicolumn{5}{c}{ Panel A: Dependant Variable: Asset } \\
\hline Variable & Coef. & Robust Std. Err & $\mathrm{z}$ & $\mathrm{p}>\mathrm{z}$ & [95\%Conf. Interval] \\
\hline inln & -0.4459409 & 0.1857097 & -2.40 & 0.016 & -0.8099253 & -0.0819565 \\
culn & -0.3159253 & 0.1581301 & -2.00 & 0.046 & -0.6258546 & -0.0059961 \\
idbt & -0.0098482 & 0.1433469 & -0.07 & 0.945 & -0.290803 & 0.2711066 \\
cdbt & 0.5847517 & 0.1201491 & 4.87 & 0.000 & 0.3492639 & 0.8202396 \\
risk1 & 12814.78 & 64573.51 & 0.20 & 0.843 & -113747 & 139376.5 \\
rgdp_gr & 117.7988 & 823.3422 & 0.14 & 0.886 & -1495.922 & 1731.52 \\
sr & 621.2839 & 819.9721 & 0.76 & 0.449 & -985.8319 & 2228.4 \\
sbgdp & -40.98711 & 141.8807 & -0.29 & 0.773 & -319.0682 & 237.0939 \\
cons & -6055.849 & 6627.665 & -0.91 & 0.361 & -19045.83 & 6934.135 \\
\hline
\end{tabular}

Random-effects GLS regression; Number of obs $=60$, Group variable: id Number of groups $=8$, R-sq: within $=0.6217$ Obs per group: $\min =3$, between $=0.8204$, avg $=7.5$, overall $=0.6480, \max =13$, Random effects u_i $\sim$ Gaussian, Wald chi2 $(8)=93.88$, corr $\left(u \_i, X\right)=0$ (assumed), Prob $>$ chi2 $=0.0000$. 
(f)

\begin{tabular}{ccccc}
\hline & Fe $(\mathrm{b})$ & $\operatorname{Re}(\mathrm{B})$ & Difference $(\mathrm{b}-\mathrm{B})$ & S.E sqrt $\left(\right.$ diag $\left.\left(\mathrm{V} \_\mathrm{b}-\mathrm{V} \_\mathrm{B}\right)\right)$ \\
\hline inln & -0.9590563 & -0.4459409 & -0.5131154 & 0.1992613 \\
culn & -0.1615069 & -0.3159253 & 0.1544184 & 0.0815065 \\
idbt & -0.3216496 & -0.0098482 & -0.3118014 & 0.1124182 \\
cdbt & 0.6761806 & 0.5847517 & 0.0914288 & 0.0178592 \\
risk1 & -15439.52 & 12814.78 & -28254.3 & 28040.54 \\
rgdp_gr & -462.7228 & 117.7988 & -580.5216 & 225.8333 \\
sr & 1463.072 & 621.2839 & 841.7881 & \\
sbgdp & -135.3294 & -40.98711 & -94.34227 & 84.84876 \\
\hline
\end{tabular}

$\mathrm{b}=$ consistent under Ho and Ha; obtained from xtreg; $\mathrm{B}=$ inconsistent under Ha, efficient under Ho; obtained from xtreg; Test: Ho: difference in coefficients not systematic, chi2 $(4)=(\mathrm{b}-\mathrm{B})^{\prime}\left[\left(\mathrm{V}_{-} \mathrm{b}-\right.\right.$ V_B $\left.)^{\wedge}(-1)\right](\mathrm{b}-\mathrm{B})=5.71$, Prob $>$ chi2 $=0.2217\left(\mathrm{~V} \_\mathrm{b}-\mathrm{V} \_\mathrm{B}\right.$ is not positive definite $)$.

could be the driving factor of lending and borrowing founds. And the other controlled variable such as the Share of Banks in the GDP, GDP per Capita are also statistically not significant and they can't explain the competitiveness of the banking sector. Analysis of coefficients shows that Inter-Banks loans, Customers loans, Inter-Banks Debts, Customers Debts have a positive impact on the Asset.

According to the results of second regression analysis (Panel B) using Profit as independent variable for competitiveness we found that only few variables (Inter-Banks loans and Customers Debts) are statistically significant, these shows that profit in banking sector depends mostly on the Inter-banks loans and Customers debts what we agree to be true because the size doesn't influence the profit, and we have discussed earlier that some small banks are making more profit compare to big banks when we take about their profit ratio.

\section{Conclusions}

The main objective of this research is to analyze the competitiveness and the driving factors in Togolese banking sector with macroeconomic development using SCP framework and regression models. The analyses are made at three levels, the Structure, the Conduct and the Performance.

Our study discovered that among the eight (8) of the commercial banks in Togo and the share in Asset of Bank in 2013, the financial bank comes first, followed by Ecobank, UTB and lastly the former Orabank which describes the environment before the merging of BTD and Financial Bank on $14^{\text {th }}$ February 2014. However, there will be a structure change years later because BRS another commercial bank has associated with the merge by forming a new Orabank. In 2015, Orabank, the merged bank has occupied the first place followed while Ecobank, Diamond bank.

Considering the profit, the concentration ration has considered the top 5 banks; the result gives us a clear picture of a dominant oligopoly industry with Ecobank and UTB leading. However, Orabank, the leading bank in Asset is not 
making profit such as Ecobank does. A bank can have more Assets but it doesn't mean that it realizes the big profit.

The conduct analysis shows that banks in Togo had relatively high interest margins reflecting low interest rates on deposits and comfortable lending rates. For the loans and deposits, the amount of short term loans is ten times superior to the long term loan. The commercial banks are willing to give more short loans and medium loans than long term loans and the overdue credit has never been stable. This fact explains perfectly the fear of Commercial banks to grant long term loans. The insolvency is a serious problem which affects considerably the performance of the Commercial Banks. Creditor's insolvency makes banks reluctant, and also destroys slowly the economy.

For the Performance, a regression model is used and the bank's competitiveness is proxied by Asset and the Profit. The period of analysis covered the years between 2000 and 2015. The results are of panel regressions with fixed effects and robust standard errors. Considering the Panel A, the variables Inter-Banks loans, Customers loans, Inter-Banks Debts, Customers Debts are statistically significant while, Risk, Savings Rate are not significant but what we noticed could be the driving factor of lending and borrowing founds. And the other controlled variables such as the Share of Banks in the GDP, GDP per Capita are also statistically not significant and they can't explain the competitiveness of the banking sector. Analysis of coefficients shows that Inter-Banks loans, Customers loans, Inter-Banks Debts, Customers Debts have a positive impact on the Asset which confirm our hypothesis $\mathrm{H} 2$. According to the results of second regression analysis (Panel B), we found that the bank's profit depends mostly on the Inter-banks loans and Customers debts what we agree to be true because the size doesn't influence the profit, what rejects our H1 (Size influences positively the competitiveness).

\section{Scope and Limitation of the Research}

This study covered only the commercial banks excluding the agriculture one due to the availability of data; meanwhile, the government is fighting against poverty in promoting agriculture. We discussed one of the important sides of giving loans to individuals and groups. The research uses banking data (profit, asset, loans, risk, saving rate, investment rate, etc.).

\section{Acknowledgements}

I would like to express my gratitude to my supervisor Mr. Chen Hongliang (沈 宏亮) for the useful remarks, comments and engagement through the learning process of this master thesis. Furthermore, I would like to thank my family and my friends: Mr. and Miss AFOLABI, Hr Jimon ORE, Dr. Victor Komla ALIPUI (Former Director of Research of the Central Bank of West African States (BCEAO)), Dean Lihua LANG, Ass. Pr. Yerang DONG, Ass. Pr. Jun DU, Miss Monika NANKELA, Miss Ashia BIO-SAWE, Miss Gaelle DIWONDI, Miss 
Yang LI and Kodjo Daniel SESSI for the help and the support during the entire process by keeping me harmonious and helping me put pieces together. Besides, I'm also grateful to the BCEAO for providing me with the data I needed to successfully complete this study.

\section{Conflicts of Interest}

The author declares no conflicts of interest regarding the publication of this paper.

\section{References}

[1] Murths, T.P., et al. (1998) Country Capabilities and the Strategic State: How National PoliticalInstitutions Affect MNC Strategies. Strategic Management Journal, 15, 113-129. https://doi.org/10.1002/smj.4250151008

[2] D’Cruz, J. and Rugman, A. (1992) New Concepts for Canadian Competitiveness. Kodak, Canada.

[3] Buckley, P.J., Pass, C.L. and Prescott, K. (1988) Measures of International Competitiveness: A Critical Survey. Journal of Marketing Management, 4, 175-200. https://doi.org/10.1080/0267257X.1988.9964068

[4] Capon, N., Farley, J.U. and Hoenig, S. (1990) Determinants of Financial Performance: A Meta-Analysis. Management Science, 36, 1137-1292.

[5] Ozdamar, O. and Giovanis, E. (2016) The Effect of Survivors' Benefits on Poverty and Health Status of Widowed Women: A Turkish Case Study. Journal of Applied Economics and Business Research, 6, 232-250.

[6] Tailab, M.M. (2014) Analyzing Factors Effecting Profitability of Non-Financial U.S. Firms. Research Journal of Finance and Accounting, 5, 17-26.

[7] Gurbuz, A.O., Aybars, A. and Kutlu, O. (2010) Corporate Governance and Financial Performance with a Perspective on Institutional Ownership: Empirical Evidence from Turkey. Journal of Applied Management Accounting Research, 8, 21-38.

[8] Karabag, S.F., Lau, M.C.K. and Suvankulov, F. (2014) Determinants of Firm Competitiveness: Case of the Turkish Textile and Apparel Industry. Journal of the Textile Institute, 105, 1-11. https://doi.org/10.1080/00405000.2013.811787

[9] Goddard, J., Tavakoli, M. and Wilson, J.O.S. (2005) Determinants of Profitability in European Manufacturing and Services: Evidence from a Dynamic Panel Model. Applied Financial Economics, 15, 1269-1282. https://doi.org/10.1080/09603100500387139

[10] Wong, Y.C.R. and Wong, M.L.S. (2001) Competition in China's Domestic Banking Industry. Cato Journal, 21, 19-41.

[11] Oberholzer \& Van der Westhuizen (2004) Productive Efficiency, Technological Change and Productivity in Portuguese Banking.

[12] Bedari, D. (2004) Cost and Profit Efficiency of Some Banks in Botswana, Namibia and South Africa.

[13] Ikhide, S.I. and Alawode, A.A. (2001) Financial Sector Reforms, Macroeconomic Instability, and the Order of Economic Liberalization: The Evidence from Nigeria. AERC Research PaperNo. 112. African Economic Research Consortium, Nairobi.

[14] Claessens, S. and Laeven, L. (2004) What Drives Bank Competition? Some International Evidence. Journal of Money, Credit, and Banking, 36, 563-584.

https://doi.org/10.1353/mcb.2004.0044 
[15] Carbo, et al. (2006) The Determinants of Bank Margins in European Banking. Journal of Banking and Finance, 31, 2043-2063. https://doi.org/10.1016/j.jbankfin.2006.06.017

[16] Staikouras, C. and Koutsomanoli-Fillipaki, A. (2006) Competition and Concentration in the New European Banking Landscape. European Financial Management, 12, 443-482. https://doi.org/10.1111/j.1354-7798.2006.00327.x

[17] Ceterelli (1999) Competitive Analysis in Banking: Appraisal of the Methodologies.

[18] Matutes and Vives (1996) Competition for Deposits, Fragility, and Insurance.

[19] Diamond and Dybvig (1983) Bank Runs, Deposit Insurance, and Liquidity.

[20] Smith, B.D. (1984) Private Information, Deposit Interest Rates, and the Stability of the Banking System. Journal of Monetary Economics, 14, 293-317. https://doi.org/10.1016/0304-3932(84)90045-X

[21] Besanko, D. and Thakor, A.V. (1993) Relationship Banking, Deposit Insurance, and Bank Portfolio Choice.

[22] Cordella and Yeyati (1998) Public Disclosure and Bank Failures.

[23] Berkely, et al. (1988) The Role of Universities in Economic Competitiveness in California.

[24] Momaya, K. (2000) Evaluating Country Competitiveness in Emerging Industries: Learning from a Case of Nanotechnology. Journal of International Business and Economy, 9, 37-58.

[25] Bartlett and Ghoshal (1989) Managing across Borders: An Empirical Test of the Bartlett and Ghoshal. Organizational Typology.

[26] Doz and Prahalad (1986) Strategic Management in Multinational Companies. Pergamon, Oxford.

[27] Hamel and Prahalad $(1989,1990)$ The Core Competence of the Corporation.

[28] Grant, R.M. () The Resource-Based Theory of Competitive Advantage: Implications for Strategy Formulation. California Management Review, 33, 114-135.

[29] Barney, J. (2001) Resource-Based Theories of Competitive Advantage: A Ten Year Retrospective on the Resource Based View. Journal of Management, 27, 643-650. https://doi.org/10.1177/014920630102700602

[30] Peteraf, M.A. (1993) The Cornerstones of Competitive Advantage: A Resource-Based View.

[31] Ulrich, D. and Jick, T. (1993) High-Impact Learning: Building and Diffusing Learning Capability. Organizational Dynamics, 22, 52-66. https://doi.org/10.1016/0090-2616(93)90053-4

[32] Balakrishan, S. and Koza, M.P. (1970) Information Asymmetry, Adverse Selection and Joint-Ventures: Theory and Evidence. Journal of Economic Behavior \& Organization, 20, 99-117.

[33] Kodjo Daniel SESSI (2013) The Efficiency of a Banking Sector: Case of Togolese Commercial Banks. 